\title{
Knowledge, Attitudes, Practices (KAP), and Financial Losses of Buffalo Raisers due to Surra among Selected Villages in Southern Philippines
}

\author{
Escarlos $\mathrm{JAJr}^{1}$, Cane $\mathrm{JF}^{2}$, Dargantes $\mathrm{AP}^{3}$ \\ ${ }^{I}$ Department of Anatomy Physiology \& Pharmacology, College of Veterinary Medicine \\ Central Mindanao University, Musuan, Bukidnon, Philippines \\ ${ }^{2}$ College of Veterinary Medicine, Central Mindanao University, Musuan, Bukidnon, Philippines \\ ${ }^{3}$ Department of Medicine and Surgery, College of Veterinary Medicine \\ Central Mindanao University, Musuan, Bukidnon, Philippines \\ E-mail: joseescarlosjr@gmail.com
}

(received 10-08-2016; revised 26-08-2016; accepted 13-09-2016)

\begin{abstract}
ABSTRAK
Escarlos JAJr, Cane JF, Dargantes AP. 2016. Tingkat pengetahuan, sikap, kebiasaaan (KAP) dan kerugian finansial peternak Kerbau akibat penyakit Surra di desa terpilih di Filipina Selatan. JITV 21(3): 190-203. DOI: http://dx.doi.org/10.14334/jitv.v21i3.1417

Penelitian ini dilakukan untuk mengukur tingkat pengetahuan, sikap, kebiasaan dan kerugian finansial peternak kerbau karena infeksi Trypanosoma evansi (surra) dan pengendaliannya di Provinsi Agusan del Sur. Sebanyak 160 peternak kerbau dari 8 desa di 4 kota di Provinsi Agusan del Sur, Mindanau, Filipina diwawancarai secara perorangan. Sebagian besar (63,65\%) responden mengetahui tentang penyakit surra dengan nilai tengah pengetahuan sebesar 12,54. Nilai tersebut tergolong masih rendah dibandingkan responden yang mengetahui tentang penyakait surra dengan baik. Kerugian finansial yang disebabkan oleh kematian ternak di 8 desa tersebut tercatat sebanyak 9,3 juta peso (US\$ $0.2 \mathrm{M}$ ) dengan penambahan kerugian dari proses pengobatan dan diagnosis berturut-turut sebanyak 657.000 peso dan 229.500 peso. Perkiraan kerugian pengobatan dan diagnosis secara keseluruhan berturut-turut adalah sebesar 2,4 dan 1,1 juta peso. Perkiraan kerugian finanasial secara keseluruhan adalah sebesar 13,7 juta peso dengan rataan sebesar 1,7 juta peso per desa. Dan diperkirakan terjadi kerugian sebesar 538 juta peso (US\$ 10,7) dari total kerugian finansial pada peternakan di Provinsi Agusan del Sur karena penyakit sura. Sebagai kesimpulan, peternak kerbau di Provinsi Agusan del Sur kurang memiliki pengetahuan, tingkah laku dan kebiasaan yang efektif dalam mengendalikan penyakit sura.
\end{abstract}

Kata Kunci: Peternak Kerbau, Surra, Filipina, KAP, Kerugian

\begin{abstract}
Escarlos JAJr, Cane JF, Dargantes AP. 2016. Knowledge, attitudes, practices (KAP) and financial losses of buffalo raisers due to Surra among selected villages in Southern Philippines. JITV 21(3): 190-203. DOI: http://dx.doi.org/10.14334/jitv.v21i3.1417

The study was conducted to assess the knowledge, attitudes, practices (KAP), and financial losses of buffalo raisers due to Trypanosoma evansi infection (surra) and its control in Agusan del Sur Province. One-hundred and sixty (160) buffalo raisers from eight villages in four municipalities (towns) in Agusan del Sur, Mindanao, Southern Philippines were personally interviewed. Majority (63.65\%) of respondents provided information about surra. Mean knowledge score of 12.54 was quite low to consider the respondents well informed about surra. Financial losses from mortalities among livestock in eight villages (in four towns) in Agusan del Sur amounted to 9.3 million Philippine Pesos (PHP) (US\$ $0.2 \mathrm{M}$ ) with additional losses for treatment and diagnosis amounting to PHP 657,000 and PHP 229,500, respectively. The estimated mass treatment and diagnostic costs were PHP 2.4 and PHP 1.1 million, respectively. The estimated overall total financial losses was PHP 13.7 million, averaging PHP 1.7 million per village, and an estimated PHP 538 million (US\$ $10.7 \mathrm{M}$ ) of total financial losses among livestock in Agusan del Sur due to surra. In conclusion, buffalo raisers in Agusan del Sur Province lack adequate knowledge, attitudes and practices to effectively control surra, a disease that has caused high financial losses among livestock in the province.
\end{abstract}

Key Words: Buffalo Raisers, Surra, Philippines, KAP, Losses

\section{INTRODUCTION}

Surra is caused by the blood protozoan parasite Trypanosoma evansi (Brun et al. 1998; Desquesnes et al. 2013b). Typically it is a wasting disease that affects a wide range of hosts resulting to chronic weight loss, anemia, subcutaneous edema, icterus, neurological abnormalities, reproductive problems, and causing deaths among thousands of animals each year (Dargantes et al. 2009; Dobson et al. 2009; Desquesnes et al. 2013b). In the last two decades, notable large epidemics have occurred in the Islands of Visayas and Mindanao in the Philippines, having high morbidity and mortality rates in horses, cattle, goats, buffaloes, and 
pigs (Manuel 1998; Dargantes et al. 2009). Agusan del Sur, a province in Eastern Mindanao, had experienced a number of these surra outbreaks particularly in buffaloes (Bubalus bubalis), animals that are important in the farming activities in the province (Reid 2002; Dargantes et al. 2009).

In Agusan Province, surra control endeavors had been centered to the identification and treatment of infected animals with very little attention given to the socio-economic impact of the disease, and the knowledge, attitudes and practices of the farmers towards the disease. Nevertheless, the level of understanding of the community about surra may greatly affect the concerted efforts towards the control of this disease. Education of farmers on the general features and impact of surra and its control is one important component in the effective and holistic approach to control the disease in the aforesaid province. Hence, there is a need to obtain this information which will definitely serve as a guide in formulating strategies to prevent further losses from surra and eventually eradicate the disease from the province.

This study was carried out to assess the knowledge, attitudes and practices of buffalo raisers in Agusan del Sur Province regarding surra (Trypanosoma evansi) and the financial losses caused by the disease among their livestock.

\section{MATERIALS AND METHODS}

\section{Time of the study and study areas}

The survey was conducted from March to December 2015 among buffalo raisers in four pre-selected municipalities of Agusan del Sur (Bunawan, Esperanza, San Francisco, Talacogon) in Mindanao, Southern Philippines. The municipalities were chosen since surra outbreaks occurred in these areas in previous years. Two villages were randomly chosen from each of the identified municipality.

\section{Research design and respondents}

This cross-sectional study utilized a total of randomly selected 160 buffalo owners from eight villages in four above mentioned municipalities as respondents. Twenty buffalo raisers were randomly selected and interviewed from each selected village. Respondents were personally interviewed using a pretested questionnaire. A focus group discussion (FGD) was done on selected (4-6) farmers in each village to validate the responses in the interviews. Farmers were requested to come to a common site in each village for the interview. They were also requested to bring their buffaloes for free veterinary consultation, deworming and vitamin supplementation services.

Government permits for the survey were sought from the Provincial Government of Agusan del Sur, the aforementioned municipalities and barangays through the Provincial Veterinary Office.

\section{Interview with respondents}

From every village, each of the 20 randomly selected buffalo owners was personally (one-on-one) interviewed using a pre-tested questionnaire with five parts, namely: Part I: Respondent's demographic information (age, education, livelihood, place of origin, and economic status) as well as some questions regarding the number of buffaloes and other animals he/she owns; Part II: Questions that assessed the respondent's level of knowledge of the disease (causative agent, transmission, clinical signs, and treatment); Part III: The respondent's attitudes towards the problems caused by surra. This part of the survey used the Likert's Scale for beliefs and feelings scoring system, consisting of a range between 1 to 5 , with 5 assuming that the farmers totally agree to the statement, and 1 assuming that the farmers totally disagree with the statement; Part IV: The respondent's prevention and control practices for surra. This part of the survey used practice frequency terms, consisting of three choices: (1) Always; (2) Sometimes; and (3) Never, indicating how frequent a respondent does a certain surra preventive activity; and Part V: Questions related to necessary information for the computation of economic losses due to surra. The interview was done in the local dialect within 5-7 minutes by 4-5 properly trained interviewers.

\section{Focus group discussion}

After the survey, an focus group discussion (FGD) was conducted in each village, to resolve any issues or any conflicting answers in the personal interviews. Four to six (20-30\% of the interviewed farmers) farmers who were interviewed were requested to participate in the FGD which was facilitated by two of the interviewers.

\section{Estimating the financial losses due to surra}

To be able to calculate the economic losses caused by surra, the following data were collected from the survey respondents: (1) Total number of animals that died of surra per species; and (2) Average selling cost of mature animals per species. Data pertaining to the total animal population in the municipalities surveyed was also retrieved from the Provincial Veterinary Office of Agusan del Sur. Basic costs (in PHP) of the 
following items were also applied as a constant to the computation (Table 1 and 2).

Table 1. Estimated treatment cost of animals with surra per species

\begin{tabular}{lc}
\hline \hline Species & Cost of surra treatment (PHP) \\
\hline Cattles & 1,500 \\
Buffaloes & 1,500 \\
Goats & 500 \\
Pigs & 1,000 \\
Horses & 1,500 \\
\hline
\end{tabular}

Table 2. Estimated diagnostic costs for animals with surra per species

\begin{tabular}{lc}
\hline \hline Species & Cost of surra treatment (PHP) \\
\hline Cattles & 500 \\
Buffaloes & 500 \\
Goats & 500 \\
Pigs & 500 \\
Horses & 500 \\
\hline
\end{tabular}

The study utilized the formulae as presented below. Only horses, pigs, buffaloes, cattles, and goats were considered in the computation since they are the only animal species that the local government are currently treating and diagnosing for surra.

\section{Data interpretation and statistical analysis}

Data were analyzed using the Statistical Package for Social Sciences (SPSS). Descriptive statistics was used in tabulating and describing the gathered data. Frequencies, totals and percentages were used to present the results of the study. Chi-square test was used to determine significant association between the respondents' profile and their KAP answers.

\section{RESULTS AND DISCUSSION}

\section{Demographic characteristics of respondents}

The result of the demographic characteristics of the buffalo owners who participated in the survey is presented in Table 3 . The respondents were mostly males $(73.8 \%)$ as the males of the household are usually the ones who take care of their draft animals. Females participated in the survey $(26.25 \%)$ because their husbands were either working in the fields or already deceased. Majority $(90 \%)$ of the participants were married, while the rest were either single or widowed. As to age profile, majority of the respondents $(24.38 \%)$ were 55 years old or older while a small proportion (2.5\%) of the respondents were aged 26-30 years old. Most of the buffalo owners have between 1-3 children $(40.63 \%)$ while the least proportion of respondents had no children at all $(7.5 \%)$.

Out of 160 respondents, $54.38 \%$ had only elementary education and only few had obtained college education $(9.38 \%)$. A high number $(63.75 \%)$ of respondents had a monthly income of less than US $\$<100$ (considered in the very low-income range), while $32.5 \%$ of the respondents had an income range between US\$ 100-200 per month. Few of the respondents $(3.75 \%)$ had an income between US $\$>200$ 300 per month. Majority $(85.63 \%)$ of the respondents owned or had leased an area of farmland while the rest $(14.38 \%)$ solely depended upon hired and paid draft work using their buffaloes for income.

Figure 1 shows the ethnic origins/groups of the respondents. Only $85 \%$ of respondents out of $160 \mathrm{had}$ an idea about their ethnic origins, and only $30.4 \%$ of these respondents are members of the indigenous tribe of Agusan del Sur (Manobo). The other respondents originated from various provinces in the Philippines with various ethnic backgrounds.

$$
\begin{aligned}
\text { Overall economic losses }= & \begin{array}{l}
\text { Total mortality losses }+ \text { Total treatment losses }+ \text { Total diagnostic losses }+ \text { Mass } \\
\text { treatment and diagnostic costs }
\end{array}
\end{aligned}
$$

Average economic losses per barangay

$=\frac{\text { Overall economic losses }}{8 \text { (number of villages surveyed })}$

Total economic losses $=$ Economic losses per barangay $\times 314$ (number of barangays in Agusan del Sur) for Agusan del Sur 


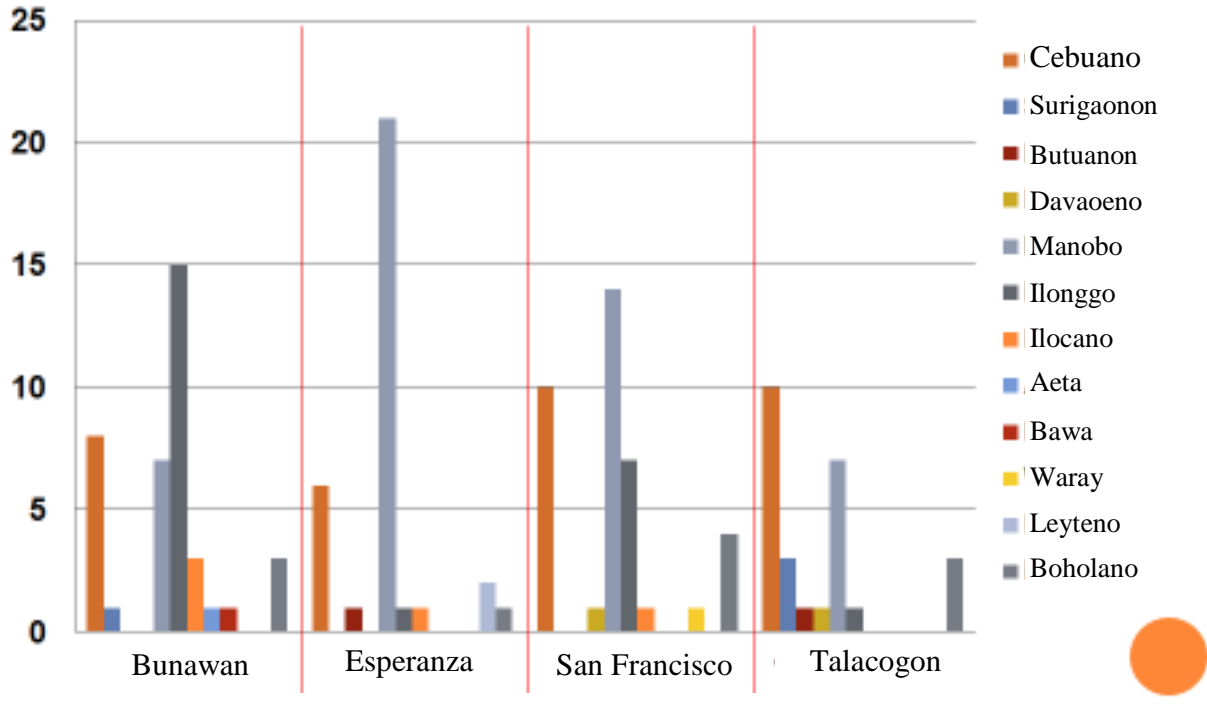

Figure 1. Ethnic group/origin of buffalo raiser respondents $(n=160)$ in Agusan del Sur, Southern Philippines.

\section{Knowledge, attitudes, and practices of survey respondents}

\section{Knowledge}

Figure 3 and Table 4 present the knowledge scores of respondents regarding etiology, transmission, hosts, clinical signs, diagnosis, treatment, control, and age by which an animal is affected by surra. Only $60.63 \%$ of respondents claimed to have heard of surra or have obtained information about surra, while $39.37 \%$ of them have not received any information at all. This distribution has severely affected the respondent scores, as those who had not heard of surra had problems in identifying the right answers to most of the questions pertaining to their knowledge about the disease. Major sources of information about surra came from their local veterinarians $(25 \%)$.

\section{Etiology}

Regardless of the respondents having heard about surra or not, only $18.12 \%$ of buffalo owners had correctly identified surra's causative agent as a parasite (Desquesnes et al. 2013b). The rest believed that it was caused by either a virus or by a bacterium, since they claimed to have not seen the physical evidence of the parasite in the feces or in the digestive tract of dead animals, which is understandable since $T$. evansi is a blood protozoan parasite (Brun et al. 1998; Desquesnes et al. 2013b). The respondents have also claimed to have never been given clear explanations on the cause of the disease, only knowing it by name and some of its clinical manifestations.

\section{Transmission}

A total of $90(64.28 \%)$ survey respondents correctly identified tabanids as the main vectors for surra (Vale 1974). They claimed to have observed that whenever a flood occurs in their area, the flies are very abundant in the muddy grazing fields where they tether their animals, and not long after seeing them around their buffaloes, their animals get sick with surra. The rainy season can be considered as a potentially higher risk of transmission of the disease since tabanid populations generally peak during these times, for tabanid larval habitats are usually muddy, aquatic or semi-aquatic in nature (Desquesnes et al. 2013a).

\section{Hosts}

Surra has a wide variety of hosts (Brun et al. 1998; Manuel 1998; Dobson et al. 2009; Desquesnes et al. $2013 \mathrm{~b}$ ), but the survey respondents regarded the buffalo as one of the main animals affected by the disease, as $86.87 \%$. It was believed that buffaloes can get sick with surra. Results for other species varied greatly, with none having approximations as high as for buffaloes. This could be because the respondents have only claimed to have heard of the term surra being used on their buffaloes, as their local dialect has many different local names for various, non-specific diseases for all their livestock animals. 
Table 3. Demographic characteristics of buffalo raisers $(n=160)$ in Agusan del Sur Province who participated in the survey

\begin{tabular}{|c|c|c|}
\hline Demographic characteristics & Number of respondents & Percentage $(\%)$ \\
\hline \multicolumn{3}{|l|}{ Sex } \\
\hline Male & 118 & 73.75 \\
\hline Female & 42 & 26.25 \\
\hline \multicolumn{3}{|l|}{ Civil status } \\
\hline Married & 144 & 90.0 \\
\hline Single & 10 & 6.25 \\
\hline Widowed & 6 & 3.75 \\
\hline \multicolumn{3}{|l|}{ Age } \\
\hline$<25$ & 5 & 3.13 \\
\hline $26-30$ & 4 & 2.50 \\
\hline $31-35$ & 13 & 8.13 \\
\hline $36-40$ & 25 & 15.63 \\
\hline $41-45$ & 28 & 17.50 \\
\hline $46-50$ & 25 & 15.63 \\
\hline $51-55$ & 21 & 13.13 \\
\hline$>55$ & 39 & 24.38 \\
\hline \multicolumn{3}{|l|}{ Number of children } \\
\hline None & 12 & 7.50 \\
\hline $1-3$ & 65 & 40.63 \\
\hline $4-6$ & 53 & 33.13 \\
\hline 7 or more & 30 & 18.75 \\
\hline \multicolumn{3}{|l|}{ Educational attainment } \\
\hline Elementary & 87 & 54.38 \\
\hline High school & 58 & 36.25 \\
\hline College & 15 & 9.38 \\
\hline \multicolumn{3}{|l|}{ Monthly income } \\
\hline$<$ PHP 5,000 $(<$ US\$ 100) & 102 & 63.75 \\
\hline PHP 5,000 - PHP 10,000 (US\$ 100-200) & 52 & 32.50 \\
\hline >PHP 10,000- PHP 15,000 (>US\$ 200-300) & 6 & 3.75 \\
\hline \multicolumn{3}{|l|}{ Owned or leased farmland } \\
\hline Yes & 137 & 85.63 \\
\hline No & 23 & 14.38 \\
\hline
\end{tabular}




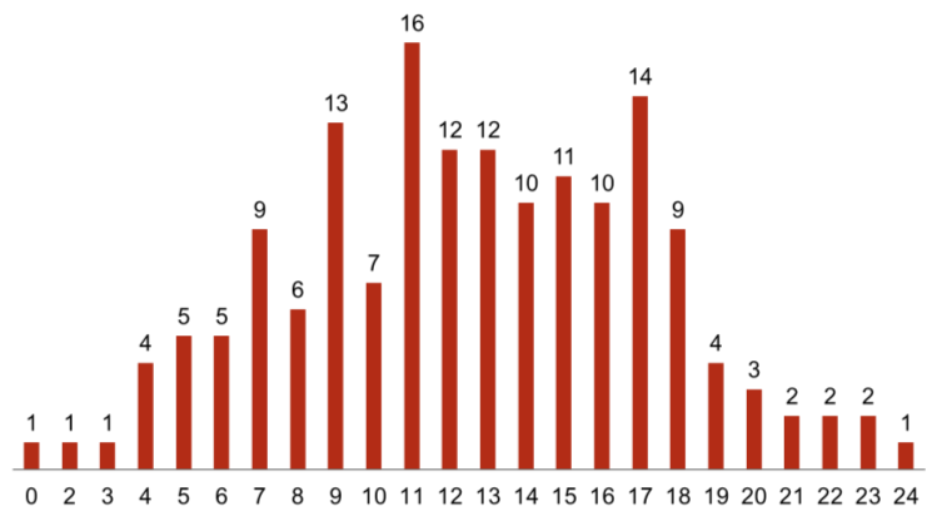

Figure 3. Knowledge scores (perfect score $=32$ ) on surra among surveyed buffalo raisers $(n=160)$ in Agusan del Sur, Sourthern Philippines.

\section{Clinical signs}

Surra has a variety of nonspecific clinical signs that could easily be manifested in other diseases of buffaloes (Dargantes et al. 2009). The farmer respondents regarded weight loss $(78.13 \%)$ as one of the main clinical signs of surra in combination with loss of condition (55.63\%) and weakness (53.75\%). Abdominal edema (Manuel 1998; Desquesnes et al. 2013b), one of the signs to look out for when one suspects surra, was only mentioned by $23.13 \%$ of respondents. Most of the respondents had a hard time distinguishing the clinical signs of surra from the clinical signs of other diseases and therefore had a hard time associating the disease directly to the symptoms they would observe.

\section{Diagnosis}

Only $56.25 \%$ of respondents knew that laboratory tests were needed to confirm cases of surra (Konnai et al. 2009; Sengupta et al. 2010; Desquesnes et al. 2013a). The rest of the respondents believed that the observation of clinical signs was enough, or by simply looking at the general appearance of the animal. Since the farmers claimed that they usually report suspected cases of surra to the local government for diagnosis when the animal is already dead or dying, there is little that the local veterinarians can do to diagnose the animal properly for the cause of death, often basing diagnosis for these animals by the clinical signs relayed by the owner. Blood collection to check animals of surra is not regularly done due to budget constraint in the government (Personal Communication Dr. Primo Calo 2014).

\section{Treatment}

Majority of the farmers $(87.5 \%)$ knew that there is available treatment for surra, yet only $3.13 \%$ have correctly identified the drugs used for treatment. From the respondents' accounts, they claimed to usually either fail to ask for the name of the medication used for treatment or are simply not told. They usually only get their animals medicated by veterinarians, and have not tried to give medication to their animals by themselves. The limited availability of the drugs in the Philippine market (Dobson et al. 2009) could also be one reason why the respondents have never heard of the drugs before. Only $59.38 \%$ of respondents knew that suspected surra cases have to be treated as soon as possible, and only $53.75 \%$ knew the average duration of treatment (within one month) (Desquesnes et al. 2013a).

\section{Control and prevention}

Among the buffalo raisers surveyed, only $53.12 \%$ believed that prophylactic drugs can help in preventing surra. The rest of the population think that treatment is only used once the animal is already sick, and are mostly afraid to have their animals treated via injections, fearing fatigue due to the medicine given or even death after medication. Lighting fires $(43.13 \%)$ and the use of fly traps $(20.63 \%)$ were also chosen as effective preventive measures, yet were not practiced effectively, particularly in the use of fly traps, as the respondents do not have access to purchase the said fly control tools. Fly traps can be purchased easily online or abroad, and can even be made, but information about it is still limited in most regions of the Philippines, and are therefore not so widely used for fly control.

Surra can affect buffaloes at any age, but the most common age answered by respondents was adulthood $(66.88 \%)$ and old age $(67.5 \%)$. In the study of Dargantes et al. (2009), higher mortalities have been noted in young buffaloes aged 2-8 years old, but from the experience of the survey respondents, their older animals are usually the first ones to get sick, although this could be because farmers usually buy their buffaloes needed for draft services at around five years of age, wherein the animal has already been trained for 
Table 4. Scores for knowledge about surra among buffalo raiser in Agusan del Sur, Southern Philippines

\begin{tabular}{|c|c|c|}
\hline Questions & Correct answers & Percentage $(\%)$ \\
\hline Etiology & 29 & 18.12 \\
\hline Transmission & 90 & 64.28 \\
\hline \multicolumn{3}{|l|}{ Hosts } \\
\hline Buffalo & 139 & 86.87 \\
\hline Cattle & 79 & 49.38 \\
\hline Horse & 64 & 40.00 \\
\hline Goat & 35 & 21.88 \\
\hline Pig & 29 & 18.13 \\
\hline Dog & 10 & 6.25 \\
\hline Sheep & 5 & 3.13 \\
\hline \multicolumn{3}{|l|}{ Clinical signs } \\
\hline Weight loss & 125 & 78.13 \\
\hline Loss of condition & 89 & 55.63 \\
\hline Weakness & 86 & 53.75 \\
\hline Fever & 44 & 27.50 \\
\hline Edema & 37 & 23.13 \\
\hline Calf mortality & 30 & 18.75 \\
\hline Abortion & 20 & 12.50 \\
\hline Anemia & 17 & 10.63 \\
\hline Orchitis & 14 & 8.75 \\
\hline Jaundice & 13 & 8.13 \\
\hline Diagnosis & 90 & 56.25 \\
\hline \multicolumn{3}{|l|}{ Treatment } \\
\hline Treatable & 140 & 87.50 \\
\hline Urgency & 95 & 59.38 \\
\hline Duration & 86 & 53.75 \\
\hline Drugs used & 5 & 3.13 \\
\hline \multicolumn{3}{|l|}{ Control } \\
\hline Prophylactic drugs & 85 & 53.12 \\
\hline Light fires & 69 & 43.13 \\
\hline Fly trap & 33 & 20.63 \\
\hline \multicolumn{3}{|l|}{ Age affected } \\
\hline Old age & 108 & 67.5 \\
\hline Adult & 107 & 66.88 \\
\hline Young adult & 92 & 57.5 \\
\hline Newborn & 81 & 50.63 \\
\hline Juvenile & 80 & 50 \\
\hline
\end{tabular}


different commands and is already able to plow land properly. Also, neonatal and calf deaths are more commonly blamed on other factors, such as malnutrition, trauma, gastrointestinal parasites, and extreme weather conditions.

Overall, the respondents' mean score in knowledge on surra was only 12.54 out of 32 possible correct answers, equating to $39.19 \%$ correct answers, which is $30.81 \%$ short compared to the $70 \%$ score needed to consider a respondent well informed about surra. With this, it is quite clear that the buffalo raisers in Agusan del Sur still lack sufficient knowledge about surra for them to be able to protect their animals against it, to possibly detect it earlier among their livestock and to help eradicate the disease in the province.

\section{Attitudes}

Figure 4 presents the answers of the respondents for surra attitude statements. Based on the median (m) answers for each question, the respondents strongly agreed with the following statements: Surra is a serious and life-threatening disease $(\mathrm{m}=5)$, as these farmers have already either experienced or heard about the effects of surra on buffaloes during outbreaks, it would be reasonable enough for them to believe that it is a damaging disease. They need to consult a veterinarian if they think their animal has surra $(m=5)$ since the farmers failed in self-medicating their animals for surra, they always try to consult and seek treatment from the nearest veterinarian. Controlling the occurrence of surra is a problem for them $(\mathrm{m}=5)$. The municipalities surveyed had already experienced surra outbreaks before, and even though there are methods available for detection of the parasite in sick animals, as well as medication, sporadic outbreaks still continuously occur (Dargantes et al. 2009; Dobson et al. 2009), this is a big problem for buffalo raisers. Downtime for sick animals, not to mention deaths of their animals that have surra, greatly affects the respondents' income and relatively, their way of life. Information about surra from the government is helpful $(\mathrm{m}=5)$, The respondents had explained that although the Provincial Veterinary Office was quick to diagnose and treat surra cases in their respective municipalities, they were not given any information about the disease itself, only truly knowing the illness by its name and some commonly observed clinical signs. It might be a greater risk if they leave their animals untreated $(m=5)$, The respondents have already seen or experienced having several untreated animals die from the disease, and therefore believe that it should be treated as soon as it is diagnosed. Animals with surra are hard to manage $(\mathrm{m}=5)$, The farmers believed that management of a sick animal is difficult, may it be sick with surra or even any other disease. Weakness, loss of condition and other clinical signs make it difficult for the owners to use their animals for draft services (Desquesnes et al. 2013b).

There should be control of movement of animals and checking for surra before they are moved $(\mathrm{m}=5)$, The respondents believed that the movement of animals should be controlled to prevent the spread of contagious diseases, surra included. In several accounts during the survey, the farmers associated buffaloes given to them for free during dispersals to the occurrence of a surra outbreak not long after being given these animals. A total of 121 beneficiaries from all around the province had received buffaloes from several government and non-government organizations (DAMRDP 2015). There is a need for a local ordinance to implement this $(\mathrm{m}=$ 5), The buffalo raisers surveyed believed that a local ordinance focused on the treatment and eradication of surra would be beneficial for the whole province. They believed that any laws that would help to control and eradicate the disease would help them greatly with their livelihood. The occurrence of the disease would definitely decrease if there is better control of animal movement, treatment programs and better diagnostic tools that could be used to identify sick animals in the field.

Respondents slightly disagreed on the following statements:

1. They are well informed about this disease $(m=2)$

Respondents believed that they need more information about surra in order to fully understand it. Better understanding about the etiology, transmission, clinical signs, and treatment of the disease will help the buffalo raisers to prevent, detect and treat surra effectively.

Respondents strongly disagreed on the following statements:

1. They can diagnose their animals suffering from surra without the help of a veterinarian $(\mathrm{m}=1)$

The respondents had a hard time knowing whether their animals have surra or not. The non-specific clinical signs and chronic nature of surra in buffaloes make it hard for them to detect surra without professional diagnosis. They highly depend on the veterinarians of the government to diagnose surra in their animals. 


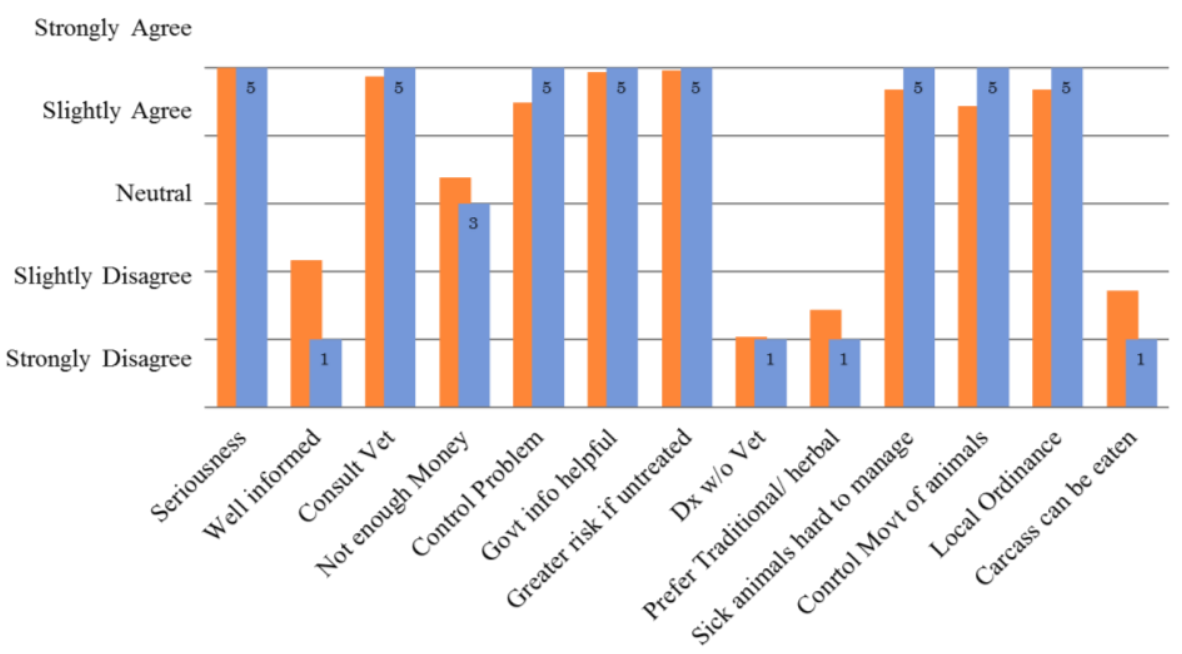

Figure 4. Attitude answers for surra of buffalo raisers in Agusan del Sur, Southern Philippines.

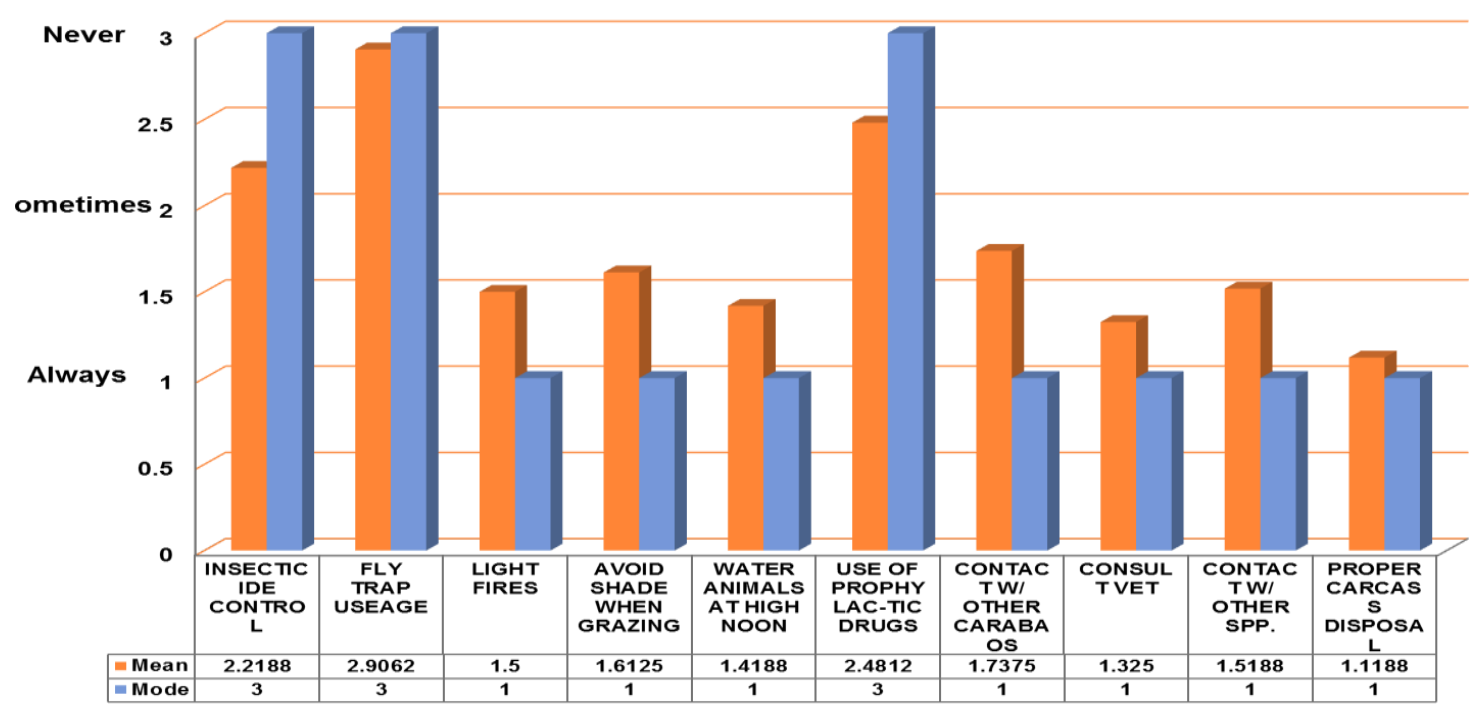

Figure 5. Surra prevention practices of farmers raising buffaloes in Agusan del Sur Province, Southern Philippines.

2. The carcass of an animal that died from surra can be eaten $(\mathrm{m}=1)$

Respondents do not believe that the meat from an animal that has died of surra should be eaten. They believed that eating the meat may cause problems like sickness or even intoxication.

The respondents neither agreed nor disagreed with the following statements:

1. They do not have enough money to buy drugs that can treat surra $(\mathrm{m}=3)$

The respondents reasoned out that having enough money for treatment was a matter of good timing.

2. They prefer traditional methods/herbal remedies to cure their animals suffering from surra $(\mathrm{m}=3.5)$
The respondents have very little trust on traditional and herbal remedies to treat surra. They have seen that this does not work on the disease from past experiences and experiences of their neighbors who had animals that died from surra before. Although they will use traditional medicine as emergency treatments whenever help cannot immediately be sought, they think that it is a temporary solution that does not really target the problem itself.

\section{Practices}

Figure 5 presents the practices of farmers raising buffaloes in Agusan del Sur Province on dealing with surra. The most common answers (mode) for each question are also presented in the Table 6. 
Table 5. Responses of buffalo raisers to attitude statements on surra

\begin{tabular}{|c|c|c|c|c|c|}
\hline \multirow[b]{2}{*}{ Statement } & \multicolumn{5}{|c|}{ Number of respondents } \\
\hline & $\begin{array}{l}\text { Strongly } \\
\text { disagree }\end{array}$ & $\begin{array}{l}\text { Slightly } \\
\text { disagree }\end{array}$ & $\begin{array}{c}\text { Neither agree/ } \\
\text { disagree }\end{array}$ & Slightly agree & $\begin{array}{c}\text { Strongly } \\
\text { agree }\end{array}$ \\
\hline Surra is a serious and life-threatening disease & 1 & 2 & 8 & 15 & 134 \\
\hline I am well informed about this disease & 79 & 21 & 32 & 11 & 17 \\
\hline $\begin{array}{l}\text { I should consult a veterinarian if I think my animal } \\
\text { has surra }\end{array}$ & 3 & 0 & 2 & 4 & 151 \\
\hline $\begin{array}{l}\text { I do not have enough money to buy drugs that can } \\
\text { treat surra }\end{array}$ & 12 & 19 & 64 & 21 & 44 \\
\hline Controlling the occurrence of surra is a problem & 2 & 11 & 12 & 16 & 119 \\
\hline $\begin{array}{l}\text { Information about surra from the government is } \\
\text { helpful }\end{array}$ & 0 & 0 & 2 & 6 & 152 \\
\hline $\begin{array}{l}\text { It might be a greater risk if I left my animal } \\
\text { untreated }\end{array}$ & 0 & 0 & 1 & 4 & 155 \\
\hline $\begin{array}{l}\text { I can diagnose my animal suffering from surra } \\
\text { without the help of a veterinarian }\end{array}$ & 92 & 19 & 18 & 13 & 18 \\
\hline $\begin{array}{l}\text { I prefer traditional methods/herbal remedies to cure } \\
\text { my animal suffering from surra }\end{array}$ & 62 & 18 & 47 & 21 & 12 \\
\hline Animals with surra are hard to manage & 1 & 3 & 11 & 15 & 130 \\
\hline $\begin{array}{l}\text { There should be control of movement of animals } \\
\text { and checking for surra before they are moved }\end{array}$ & 5 & 5 & 15 & 24 & 111 \\
\hline I think we need a local ordinance to implement this & 1 & 3 & 12 & 14 & 130 \\
\hline $\begin{array}{l}\text { The carcass of an animal that died from surra can } \\
\text { be eaten }\end{array}$ & 112 & 11 & 18 & 8 & 11 \\
\hline
\end{tabular}

Table 6. Practices on dealing with surra among farmers raising buffaloes in Agusan del Sur Province, Southern Philippines

\begin{tabular}{lccc}
\hline \hline \multirow{2}{*}{ Practices } & \multicolumn{3}{c}{ Respondents' answers } \\
\cline { 2 - 4 } & Always & Sometimes & Never \\
\hline Insecticide control & $35(21.88 \%)$ & $53(33.13 \%)$ & $72(45 \%)$ \\
Fly trap usage & $3(1.88 \%)$ & $9(5.63 \%)$ & $148(92.5 \%)$ \\
Light fires & $95(59.38 \%)$ & $49(30.63 \%)$ & $16(10 \%)$ \\
Avoid shade when grazing & $13(8.13 \%)$ & $72(45 \%)$ & $75(46.88 \%)$ \\
Water animals at high noon & $107(66.88 \%)$ & $39(24.38 \%)$ & $14(8.75 \%)$ \\
Use of prophylactic drugs & $11(6.885)$ & $61(38.13 \%)$ & $88(55 \%)$ \\
Contact with other carabaos & $27(16.88 \%)$ & $63(39.38 \%)$ & $70(43.75 \%)$ \\
Consult veterinarian & $116(72.5 \%)$ & $36(22.5 \%)$ & $8(5 \%)$ \\
Contact with other spp & $20(12.5 \%)$ & $44(27.5 \%)$ & $96(60 \%)$ \\
Proper carcass disposal & $144(90 \%)$ & $13(8.12)$ & $(1.88 \%)$ \\
\hline
\end{tabular}


Based on the median (m) answers for each question, the survey respondents always practiced the following:

1. Light fires $(m=1)$

The respondents would usually light fires in the afternoon, to keep away mosquitoes, tabanids, and other insects.

2. Water animals at high noon $(\mathrm{m}=1)$

The farmers would often leave their animals to wallow in mud and drink water at high noon so that they will no longer be thirsty for the rest of the day and will have a protective layer of mud against biting flies and mosquitoes.

3. Consult a veterinarian when an animal is sick $(\mathrm{m}=$ 1)

Since access to the local government veterinarians is attainable, most of the respondents would always consult a veterinary doctor when their animals are sick.

4. Contact with other animal species $(m=1)$

Just like with other buffaloes, contact between the respondents' buffaloes and other species of animals is unavoidable, especially with cattle, cats and dogs.

5. Proper carcass disposal $(\mathrm{m}=1)$

The respondents always properly buried their dead animals to avoid getting sick themselves and to prevent other animals from getting sick. practices:

The respondents sometimes did the following

1. Insecticide control $(\mathrm{m}=2)$

The use of insecticide for pest control is not a common practice for the buffalo raisers in Agusan del Sur.

2. Contact with other buffaloes $(m=2)$

Respondents said that contact with other buffaloes within or outside of their respective barangays is unavoidable.

Most respondents never did the following practices.

1) Fly trap usage $(m=3)$, fly traps are not well known in the survey areas and therefore have not been used by the respondents to control flies in their respective farmlands. 2) Avoid shade when tethering their buffaloes $(\mathrm{m}=3)$, buffalo raisers would usually keep their animals in the shade to avoid heatstroke while being tethered. 3) Use of prophylactic drugs $(m=3)$ Since the respondents do not have access to drugs being used to prevent surra, they have never tried giving prophylactic treatment to their animals on their own.

\section{Association between respondent's demography and KAP scores}

Only age has a significant association on the surra knowledge scores of the survey respondents. Female respondents tend to have higher knowledge scores than males. Scores on attitudes and practices for surra were unaffected by the buffalo raiser's demography. This findings conforms with the previous findings in other country (Cheraghli et al. 2014). The scores were highest among housekeepers since majority of housekeepers are female, related to housewives spending more time obtaining health information from different sources, as well as increased possibility of women in the community communicating and sharing this information to others. Similarly, the women in the towns surveyed are housewives who stay at home or tend to gardens and their farms, leaving the draft work to their male counterparts. Information, confirmation and discussion about the disease whenever an outbreak occurs are done more by females than males.

\section{Financial losses}

Tables 7 to 11 present the different financial losses due to surra in Agusan del Sur Province. The overall estimated economic losses for the four municipalities surveyed reached 13.7 million Philippine Pesos (PHP), with estimated losses per barangay of PHP 1.7 million and a calculated economic loss of PHP 538 million for the whole province (from a total of 314 barangays). IThe study including the same area reported in 2009 (Dobson et al. 2009), an estimated PHP 7.9 million (US\$ 158,000) per annum is lost in every village without effective surra control. However, the previous study had also included losses from abortion, calf mortality and costs of replacement animals, thus the big difference. It can also be taken into consideration that the financial losses in the municipalities surveyed has decreased due to several factors, including the unrecorded cases of surra outbreaks or undiagnosed isolated cases, as well as the subtraction of mass treatment and diagnostic costs for pigs and animal mortalities unaccounted for by the survey respondents. Another factor could be the continuous efforts of the Provincial Veterinary Office to do mass treatments and early detection of the disease, as mortalities have greatly reduced. Sustainability of these efforts would affect the losses to a greater extent, and regular monitoring and treatments could eventually eradicate surra from Agusan del Sur Province. 
Escarlos et al. Knowledge, attitudes, practices (KAP) and financial losses of buffalo raisers due to Surra among selected villages

Table 7. Total financial losses of buffalo raisers $(n=160)$ in eight villages (in four towns) of Agusan del Sur Province, Southern Philippines from surra mortality among their livestock

\begin{tabular}{lcccccc}
\hline \hline \multirow{2}{*}{ Village } & \multicolumn{5}{c}{ Losses (PHP) } \\
\cline { 2 - 7 } & Cattle & Buffalo & Goat & Pig & Horse & Per village \\
\hline Poblacion, Bunawan & 0 & 65,684 & 0 & 39,722 & 0 & 105,406 \\
San Andres, Bunawan & 44,000 & 331,667 & 0 & 0 & 0 & 375,667 \\
Borbon, San Francisco & 0 & 868,000 & 0 & 0 & 20,000 & 888,000 \\
Ladgadan, San Francisco & 606,625 & 524,400 & 0 & 0 & 312,500 & $1,443,525$ \\
Mahagkot, Esperanza & 573,067 & $2,778,000$ & 0 & 0 & 0 & $3,351,067$ \\
Cubo, Esperanza & 0 & 580,500 & 9,341 & 86,032 & 0 & 675,873 \\
Labnig, Talacogon & 33,454 & 620,000 & 26,818 & 13,626 & 0 & 693,898 \\
Kauswagan, Talacogon & 19,083 & $1,725,105$ & 0 & 0 & 0 & $1,744,188$ \\
\hline Total per species & $1,276,229$ & 493,356 & 36,159 & 139,380 & 332,500 & $9,277,624$ \\
\hline Total losses, mortality & & & & & & 0 \\
\hline
\end{tabular}

Table 8. Total treatment costs for surra among livestock spent by buffalo raisers $(n=160)$ in eight villages (in four towns) of Agusan del Sur Province, Southern Philippines

\begin{tabular}{lcccccc}
\hline \hline \multirow{2}{*}{ Village } & \multicolumn{5}{c}{ Treatment costs (PHP) } \\
\cline { 2 - 7 } & Cattle & Buffalo & Goat & Pig & Horse & Per village \\
\hline Poblacion, Bunawan & 0 & 4,500 & 0 & 10,000 & 0 & 14,500 \\
San Andres, Bunawan & 3,000 & 22,500 & 0 & 0 & 0 & 25,500 \\
Borbon, San Francisco & 0 & 52,500 & 0 & 0 & 3,000 & 55,500 \\
Ladgadan, San Francisco & 34,500 & 34,500 & 0 & 0 & 37,500 & 106,500 \\
Mahagkot, Esperanza & 42,000 & 180,000 & 0 & 0 & 0 & 222,000 \\
Cubo, Esperanza & 0 & 40,500 & 2,000 & 22,000 & 0 & 64,500 \\
Labnig, Talacogon & 3,000 & 46,500 & 5,000 & 3,000 & 0 & 57,500 \\
Kauswagan, Talacogon & 1,500 & 109,500 & 0 & 0 & 0 & 111,000 \\
\hline Total treatment cost per species & 84,000 & 490,500 & 7,000 & 35,000 & 40,500 & \\
\hline Treatment cost per species & 1,500 & 1,500 & 500 & 1,000 & 1,500 & 657,000 \\
\hline Total treatment cost & & & & & \\
\hline
\end{tabular}

Table 9. Diagnostic costs for surra among livestock spent by buffalo raisers $(n=160)$ in eight villages (in four towns) of Agusan del Sur Province, Southern Philippines

\begin{tabular}{lcccccc}
\hline \hline \multirow{2}{*}{ Village } & \multicolumn{5}{c}{ Diagnostic costs (PHP) } \\
\cline { 2 - 7 } & Cattle & Buffalo & Goat & Pig & Horse & Per village \\
\hline Poblacion, Bunawan & 0 & 1,500 & 0 & 5,000 & 0 & 6,500 \\
San Andres, Bunawan & 1,000 & 7,500 & 0 & 0 & 0 & 8,500 \\
Borbon, San Francisco & 0 & 17,500 & 0 & 0 & 1,000 & 18,500 \\
Ladgadan, San Francisco & 11,500 & 11,500 & 0 & 0 & 12,500 & 35,500 \\
Mahagkot, Esperanza & 14,000 & 60,000 & 0 & 0 & 0 & 74,000 \\
Cubo, Esperanza & 0 & 13,500 & 2,000 & 11,000 & 0 & 26,500 \\
Labnig, Talacogon & 1,000 & 15,500 & 5,000 & 1,500 & 0 & 23,000 \\
Kauswagan, Talacogon & 500 & 36,500 & 0 & 0 & 0 & 37,000 \\
\hline Total diagnostic cost per species & 28,000 & 163,500 & 7,000 & 17,500 & 13,500 & \\
\hline Diagnostic cost per species & 500 & 500 & 500 & 500 & 500 & \\
\hline Total diagnostic costs & & & & & 229,500 \\
\hline
\end{tabular}


Table 10.Total mass treatment costs among livestock against surra in eight villages (in four towns) of Agusan del Sur Province, Southern Philippines

\begin{tabular}{|c|c|c|c|c|c|c|}
\hline \multirow{2}{*}{ Village } & \multicolumn{6}{|c|}{ Costs (PHP) } \\
\hline & Cattle & Buffalo & Goat & Pig & Horse & Per village \\
\hline Poblacion, Bunawan & 9,000 & 322,500 & 67,500 & 0 & 0 & 399,000 \\
\hline San Andres, Bunawan & 9,000 & 60,000 & 12,500 & 0 & 7,500 & 89,000 \\
\hline Cubo, Esperanza & 15,000 & 105,000 & 30,000 & 0 & 0 & 150,000 \\
\hline Labnig, Talacogon & 10,500 & 127,500 & 48,500 & 0 & 0 & 186,500 \\
\hline Borbon, San Francisco & 34,500 & 487,500 & 196,500 & 0 & 3,000 & 721,500 \\
\hline Ladgadan, San Francisco & 21,000 & 54,000 & 63,000 & 0 & 37,500 & 175,500 \\
\hline Mahagkot, Esperanza & 195,000 & 180,000 & 30,000 & 0 & 0 & 405,000 \\
\hline Kauswagan, Talacogon & 42,000 & 165,000 & 68,500 & 0 & 0 & 275,500 \\
\hline Total mass treatment cost per species & 336,000 & $1,501,500$ & 516,500 & 0 & 48,000 & \\
\hline Total mass treatment cost & & & & & & $2,402,000$ \\
\hline
\end{tabular}

Table 11.Total mass diagnostic costs for surra among livestock in eight villages (in four towns) of Agusan del Sur, Southern Philippines

\begin{tabular}{lcccccc}
\hline \hline \multirow{2}{*}{ Village } & \multicolumn{7}{c}{ Costs (PHP) } \\
\cline { 2 - 7 } & Cattle & Buffalo & Goat & Pig & Horse & Per village \\
\hline Poblacion, Bunawan & 3,000 & 107,500 & 67,500 & 0 & 0 & 178,000 \\
San Andres, Bunawan & 3,000 & 20,000 & 12,500 & 0 & 2,500 & 38,000 \\
Borbon, San Francisco & 11,500 & 162,500 & 196,500 & 0 & 1,000 & 371,500 \\
Ladgadan, San Francisco & 7,000 & 18,000 & 63,000 & 0 & 12,500 & 100,500 \\
Mahagkot, Esperanza & 65,000 & 60,000 & 30,000 & 0 & 0 & 155,000 \\
Cubo, Esperanza & 5,000 & 35,000 & 30,000 & 0 & 0 & 70,000 \\
Labnig, Talacogon & 3,500 & 42,500 & 48,500 & 0 & 0 & 94,500 \\
Kauswagan, Talacogon & 14,000 & 55,000 & 68,500 & 0 & 0 & 137,500 \\
Mass diagnostic cost per species & 112,000 & 500,500 & 516,500 & 0 & 16,000 & $1,145,000$ \\
\hline Total diagnostic cost & & & & & & 0 \\
\hline
\end{tabular}

Table 12.Total financial losses (PHP) due to surra among livestock in eight villages (in four towns) of Agusan del Sur, Southern Philippines

\begin{tabular}{lc}
\hline \hline Type of loss & Amount \\
\hline Total losses from mortalities & $9,277,624$ \\
Total losses from treatment costs & 657,000 \\
Total losses from diagnostic costs & 229,500 \\
Total mass treatment costs/losses & $2,402,000$ \\
Total mass diagnostic costs/losses & $1,145,000$ \\
Overall total losses among eight survey villages & $13,711,124$ \\
Average loss per village & $1,713,890$ \\
\hline Estimated total losses for Agusan del Sur & $538,161,617$ \\
\hline
\end{tabular}

Table 12 shows the total financial losses from surra among livestock for the four barangays surveyed, as well as the total losses for each barangay and the estimated losses for the whole province, assuming that each of the 314 barangays in Agusan del Sur has the 
same economic losses as the barangays included in the study.

\section{CONCLUSION}

This research results support the conclusions that (1) buffalo raisers in Agusan del Sur, Southern Philippines lack adequate knowledge, attitudes and practices that are necessary for an effective surra control; and (2) these farmers suffer from high financial losses due to surra affecting their livestock.

\section{ACKNOWLEDGEMENT}

We are grateful to the GREASE Network and Central Mindanao University for the financial support. We thank also the officials of the Province of Agusan del Sur, the municipalities and villages surveyed, and the farmers for allowing us to conduct the survey. The technical assistance of Drs. Regine Paciente, Cindy Rose Villordon, Manuel Antonio Sison Jr., Primo Calo, Maricel Ampo and Joriz Elevazo, and livestock technicians during the field survey are also highly acknowledged.

\section{REFERENCES}

Brun R, Hecker H, Lun ZR. 1998. Trypanosoma evansi and $T$. equiperdum: distribution, biology, treatment and phylogenetic relationship (a review). Vet Parasitol. 79:95-107.

Cheraghli Z, Okhovat B, Irani A, Gooya M. 2014 Knowledge, attitude and practices regarding food and waterborne outbreak after massive diarrhea outbreak in Yazd Province, Iran. International Scholarly Research Notices. p. 7-14.
Dargantes AP, Mercado RT, Dobson RJ, Reid SA. 2009. Estimating the impact of Trypanosoma evansi infection (surra) on buffalo population dynamics in southern Philippines using data from cross-sectional surveys. Int J Parasitol. 39:1109-1114.

Desquesnes M, Dargantes A, Lai DH, Lun ZR, Holzmuller P, Jittapalapong S. 2013a. Trypanosoma evansi and surra: A review and perspectives on transmission, epidemiology and control, impact, and zoonotic aspects. BioMed Res Int. 2013:1-27.

Desquesnes M, Holzmuller P, Lai DH, Dargantes A, Lun ZR, Jittapalapong S. 2013b. Trypanosoma evansi and surra: a review and perspectives on origin, history, distribution, taxonomy, morphology, hosts, and pathogenic effects. BioMed Res Int. 2013:1-22.

Dobson RJ, Dargantes AP, Mercado RT, Reid SA. 2009. Models for Trypanosoma evansi (surra), its control and economic impact on small-hold livestock owners in the Philippines. Int J Parasitol. 39:1115-1123.

Konnai S, Mekata H, Mingala CN, Abes NS, Gutierrez CA, Herrera JRV, Dargantes AP, Witola WH, Cruz LC, Inoue N, Onuma M, Ohashi K. 2009. Development and application of a quantitative real-time PCR for the diagnosis of Surra in water buffaloes. Infect Genet Evol. 9:449-452.

Manuel MF. 1998. Sporadic outbreaks of Surra in the Philippines. J Protozool Res. 8:131-138.

Reid SA. 2002. Trypanosoma evansi control and containment in Australasia. Trends Parasitol. 18:219-224.

Sengupta PP, Balumahendiran M, Suryanaryana VVS, Raghavendra AG, Shome BR, Gajendragad MR, Prabhudas K. 2010. PCR-based diagnosis of surratargeting VSG gene: Experimental studies in small laboratory rodents and buffalo. Vet Parasitol. 171: 22-31. 